\title{
Canadian patterns of antimicrobial resistance: Overview of current trends related to hospital pathogens
}

\author{
Tony Mazzulli MD FRCPC
}

\begin{abstract}
T Mazzulli. Canadian patterns of antimicrobial resistance: Overview of current trends related to hospital pathogens. Can J Infect Dis Med Microbiol 2006;17(Suppl B):3B-5B.
\end{abstract}

Selection of appropriate empirical antibiotic therapy is dependent on many factors, not the least of which is an understanding of antimicrobial resistance rates in the patient population that is undergoing treatment. Resistance rates may vary by geographical location, institution, hospital ward or unit, and even body site of infection. The present paper reviews the currently available Canadian data regarding resistance rates for some of the most common hospital-acquired pathogens, including Escherichia coli, Klebsiella species, Pseudomonas aeruginosa, Enterobacter species, Staphylococcus aureus and Enterococcus species. Current data suggest that the rates of extended-spectrum beta-lactamases among E coli and Klebsiella species remain relatively low across Canada. There are very little data on the epidemiology of ampC cephalosporinases among Gram-negative organisms, although combined American and Canadian data suggest that ceftazidime resistance rates for Enterobacter species range from $17.1 \%$ to $24.8 \%$. The increased use of fluoroquinolones has led to an increase in resistance rates among most Gram-negative organisms. In the late 1990s, ciprofloxacin resistance rates for $P$ aeruginosa were reported to be approximately 20\%. For the Gram-positive organisms, methicillin resistance rates for $S$ aureus have been reported to be as high as $10 \%$ and vancomycin resistance rates for Enterococcus species have been reported to be less than $1 \%$. Additional data that are representative of all regions of Canada are needed. Continued surveillance, antibiotic stewardship, and adherence to good infection prevention and control measures will lead to a better understanding of the epidemiology of antimicrobial resistance in Canadian hospitals, as well as help to control its spread.

Key Words: Antimicrobial resistance; Hospital pathogens; Surveillance

\section{La résistance aux antimicrobiens au Canada : Aperçu des tendances actuelles concernant les agents pathogènes dans les hôpitaux}

Le choix d'un traitement antibiotique empirique, approprié dépend de nombreux facteurs, dont, et non pas le moindre, la compréhension des taux de résistance aux antimicrobiens chez les patients soumis à ce type de traitement. Les taux de résistance peuvent varier selon les lieux géographiques, les établissements, les salles de malades ou les services dans les hôpitaux et même les foyers d'infection dans l'organisme. Le présent article passe en revue les données actuellement disponibles au Canada sur les taux de résistance de certains des agents pathogènes le plus souvent mis en cause dans les infections nosocomiales, notamment Escherichia coli, les espèces Klebsiella, Pseudomonas aeruginosa, les espèces Enterobacter, Staphylococcus aureus et les espèces Enterococcus. D'après les données actuelles, les taux de résistance aux bêta-lactamases à spectre étendu parmi les espèces E. coli et Klebsiella resteraient relativement faibles partout au Canada. Par ailleurs, l'on dispose de très peu de données sur l'épidémiologie des céphalosporinases de type AmpC parmi les microorganismes gram-négatifs, même si, d'après des données américaines et canadiennes, les taux de résistance à la ceftazidime parmi les espèces Enterobacter varieraient de $17,1 \%$ à $24,8 \%$. L'utilisation accrue des fluoroquinolones a entraîné une augmentation des taux de résistance chez la plupart des germes gram-négatifs. À la fin des années 1990, les taux de résistance de $P$. aeruginosa à la ciprofloxacine se situaient aux alentours de $20 \%$. Quant aux germes gram-positifs, les taux de résistance de S. aureus à la méthicilline s'élèveraient jusqu'à $10 \%$, mais les taux de résistance des espèces Enterococcus à la vancomycine seraient inférieurs à $1 \%$. Il faut donc poursuivre la collecte de données qui soient représentatives de toutes les régions du Canada. Une surveillance continue, une utilisation judicieuse des antibiotiques ainsi que le respect des mesures de prévention des infections et de lutte contre ces maladies nous permettront de mieux comprendre l'épidémiologie de la résistance aux antimicrobiens dans les hôpitaux au Canada et ainsi de mieux combattre leur transmission.

antibiotic resistance may result in an increased risk of ineffective initial therapy.

Because resistance rates may vary significantly from one geographical area to another, from institution to institution, from hospital unit or ward to hospital unit or ward, and even by body site of infection, one must have an understanding of the resistance issues in the particular patient population and setting in which one is working. As well, unless the surveillance network collecting and reporting the data accounts for these and other factors that may affect the information provided, it is extremely difficult to compare the results presented in different studies. Therefore, although an attempt is made to review the most recently published Canadian resistance data within the hospital setting, one must be cautious in generalizing

Department of Microbiology, Mount Sinai Hospital, and the Department of Laboratory Medicine and Pathobiology, University of Toronto, Toronto, Ontario

Correspondence and reprints: Dr Tony Mazzulli, Department of Microbiology, Mount Sinai Hospital, 600 University Avenue, Toronto, Ontario

M5G 1X5. Telephone 416-586-4695, fax 416-586-8746, e-mail tmazzulli@mtsinai.on.ca 
the information available and in comparing the results presented in different studies.

Due to the paucity of data available for some organisms and the limited scope of the present review, not all issues of antimicrobial resistance are discussed. An attempt is made to highlight some features of the most common resistance issues encountered in the hospital setting. One must keep in mind not only the rates of resistance for a given organism, but also the frequency with which a given organism is isolated. Data from several studies have shown that Gram-positive organisms account for approximately two-thirds of nosocomial bloodstream infections, while Gram-negative organisms account for the remaining one-third (4). Within these groups, Escherichia coli, Klebsiella species, Pseudomonas aeruginosa and Enterobacter species make up the majority of the Gram-negative organisms, while coagulase-negative staphylococci, Staphylococcus aureus and Enterococcus species make up the majority of the Grampositive organisms. A broad overview of the susceptibility patterns for these key organisms (with the exception of coagulase-negative staphylococci) is presented.

\section{EXTENDED-SPECTRUM BETA-LACATAMASE- PRODUCING E COLI AND KLEBSIELLA SPECIES}

The production of extended-spectrum beta-lacatamase-producing E coli and Klebsiella species (ESBLs) (Ambler class A) was first reported in the early 1980s (5). Since that time, more than 200 variants of these enzymes have been described worldwide. The genes that code for these enzymes are usually found on plasmids and are often associated with resistance to other classes of agents. The minimum inhibitory concentrations (MICs) for these organisms are only modestly increased ( $1 \mu \mathrm{g} / \mathrm{mL}$ to $8 \mu \mathrm{g} / \mathrm{mL})$ and they are usually, but not always, inhibited by beta-lactamase inhibitors. Mulvey et al (6) reported the rates of ESBLs in a recently published survey of 29,323 E coli and 5156 Klebsiella species collected from 12 tertiary care centres across Canada from October 1999 to September 2000. Seventy-four $(0.26 \%$, range $0 \%$ to $1.79 \%)$ E coli and $42(0.81 \%$, range $0 \%$ to $3.25 \%$ ) Klebsiella species were found to be ESBLs. These rates compare favourably with those reported from the United States, where different studies have found that $2 \%$ to $10 \%$ of E coli and $5 \%$ to $15 \%$ of Klebsiella species are ESBLs $(7,8)$. Because there were no comparable Canadian data before the study by Mulvey et al, it is difficult to determine whether rates are stable or changing. Although data for only a small subset of non-ESBLs were presented, it does appear that ESBLs are more likely to be resistant to other classes of agents, including fluoroquinolones, aminoglycosides and trimethoprim-sulfamethoxazole.

\section{ampC CEPHALOSPORINASES AND THIRD. GENERATION CEPHALOSPORIN RESISTANCE IN ENTEROBACTERIACEAE}

Very little Canadian data are available on the epidemiology of ampC (Ambler class C) cephalosporinases among Gramnegative organisms. This mechanism of resistance is an intrinsic property of numerous Gram-negative bacilli and is usually expressed at low levels. However, it is inducible, particularly by cephamycins and carbapenems, and may occur during therapy, resulting in stable derepression and hyperproduction. The level of resistance tends to be high, with MICs of $8 \mu \mathrm{g} / \mathrm{mL}$ or greater. The clinical significance of this resistance is unmistakable, as evidenced by patients failing therapy with all penicillins, cephalosporins, beta-lactam/beta-lactamase inhibitor combinations and monobactams. In vitro resistance of Enterobacter species and certain other enterobacteriaceae to ceftazidime and other third-generation cephalosporins is often used as a marker of this type of resistance in vitro (7). The SENTRY surveillance program in North America, which included both Canadian and American centres, recently published data on the rates of ceftazidime resistance among Enterobacter species from bloodstream infections (9). Of 1575 isolates collected between 1997 and 2002, resistance to ceftazidime ranged from $17.1 \%$ in 2002 to $24.8 \%$ in 1998 . The activity of cefepime, the only other agent for which activity against Enterobacter species was reported, remained at approximately $99 \%$ or greater. Although the provinces of Alberta, Manitoba, Nova Scotia, Ontario and Quebec were represented throughout all six years of the study, the resistance rates for the Canadian centres specifically could not be determined. Earlier studies have shown that prior exposure to a third-generation cephalosporin is a major risk factor for infection with a ceftazidime-resistant organism (10).

\section{FLUOROQUINOLONE-RESISTANT $P$ AERUGINOSA}

Fluoroquinolones have become extremely popular in the treatment of $P$ aeruginosa infections because of their good safety profiles and proven efficacy. However, with their increasing use both in the hospital setting and in the community, increasing resistance has emerged. In a survey of $6783 \mathrm{P}$ aeruginosa isolates collected from five to eight centres in Canada between 1997 and 1999, ciprofloxacin resistance remained stable at $19.0 \%$ to $20.1 \%(11)$. In the same survey, ciprofloxacin resistance rates among $P$ aeruginosa isolates collected from 26 to 28 centres in the United States (28,870 isolates) were $20.2 \%$ to $24.6 \%$ (11). Resistance rates among other antipseudomonal agents were as follows: ceftazidime, $15.3 \%$ to $19.8 \%$; imipenem, $8 \%$ to $17 \%$; tobramycin, $5.85 \%$ to $8.6 \%$; and piperacillin/ tazobactam, $4.4 \%$ to $6.8 \%$. Some have shown that the trend toward increasing fluoroquinolone resistance among $P$ aeruginosa is associated with the overall increasing use of fluoroquinolones, while others have suggested that it is a result of the use of specific members of this class of agents (12-15).

\section{METHICILLIN-RESISTANT S AUREUS}

The first Canadian methicillin-resistant $S$ aureus (MRSA) isolate was reported in 1981 (16). Since that time, many surveys of MRSA rates in Canadian hospitals have been conducted. One of the most recent and comprehensive data sets comes from the Canadian Nosocomial Infection Surveillance Program, which was established in 1994. Data from 22 to 34 hospitals from nine provinces found that the overall MRSA rate (based on 4507 infected and/or colonized patients) in Canadian hospitals in 1999 was approximately $6 \%$, an increase of more than $5 \%$ over the rate from 1995 (17). The greatest increase in MRSA occurred in Ontario, Quebec and the western provinces. Subsequent studies have reported rates of $8.3 \%$ in 2000 and $10 \%$ in 2003 (Health Canada, unpublished data; 18-20). In the United States, the National Nosocomial Infection Surveillance program has reported MRSA rates of greater than $50 \%$ in several hospitals across the country (21). Since the early 1990s, there have been several reports of community-acquired MRSA in Canada (22). These patients may bring the organism with them when they enter hospitals and, thus, become a potential source for spread if they are not identified early and if appropriate infection control measures 
COPYRIGHT PULSUS GROP

are not implemented. To date, there have been
reports in Canada of vancomycin-resistant $S$ aureus.

\section{VANCOMYCIN-RESISTANT ENTEROCOCCUS SPECIES}

Enterococci tend to be intrinsically resistant to a number of antibiotics. Even for those agents that are considered to be active against enterococci, the MICs tend to be at or near the break points. The emergence of vancomycin-resistant enterococci (VRE) has raised concerns because of the limited options for therapy. Fortunately, in Canada, the rates of VRE have remained relatively low, with most data suggesting rates of less than $0.2 \%(17-19)$. In contrast, VRE rates in the United States continue to rise, with rates as high as $25 \%$ being reported in some centres (22). Despite the low rates in Canada, several VRE outbreaks have been reported in at least three different centres in Ontario, Saskatchewan and Quebec, and thus, the importance of these organisms should not be underestimated $(19,23,24)$. The use of third-generation cephalosporins and vancomycin has been correlated with the prevalence of VRE in the hospital setting $(25,26)$. To date, no study has been published

\section{REFERENCES}

1. Ibrahim EH, Sherman G, Ward S, Fraser VJ, Kollef MH. The influence of inadequate antimicrobial treatment of bloodstream infections on patient outcomes in the ICU setting. Chest 2000;118:146-55.

2. Valles J, Rello J, Ochagavia A, Garnacho J, Alcala MA. Communityacquired bloodstream infection in critically ill adult patients: Impact of shock and inappropriate antibiotic therapy on survival. Chest 2003;123:1615-24.

3. Kolleff MH, Fraser VJ. Antibiotic resistance in the intensive care unit. Ann Intern Med 2001;134:298-314.

4. Wisplinghoff H, Bischoff T, Tallent SM, Seifert H, Wenzel RP, Edmond MB. Nosocomial bloodstream infections in US hospitals: Analysis of 24,179 cases from a prospective nationwide surveillance study. Clin Infect Dis 2004;39:309-17. (Erratum in 2004;39:1093).

5. Knothe H, Shah P, Krcmery V, Antal M, Mitsuhashi S. Transferable resistance to cefotaxime, cefoxitin, cefamandole and cefuroxime in clinical isolates of Klebsiella pneumoniae and Serratia marcescens. Infection 1983;11:315-7.

6. Mulvey MR, Bryce E, Boyd D, et al. Ambler class A extended-spectrum beta-lactamase-producing Escherichia coli and Klebsiella spp. in Canadian hospitals. Antimicrob Agents Chemother 2004;48:1204-14.

7. Jones RN, Biedenbach DJ, Gales AC. Sustained activity and spectrum of selected extended-spectrum beta-lactams (carbapenems and cefepime) against Enterobacter spp. and ESBL-producing Klebsiella spp.: Report from the SENTRY antimicrobial surveillance program (USA, 1997-2000). Int J Antimicrob Agents 2003;21:1-7.

8. Itokazu GS, Quinn JP, Bell-Dixon C, Kahan FM, Weinstein RA. Antimicrobial resistance rates among aerobic gram-negative bacilli recovered from patients in intensive care units: Evaluation of a national postmarketing surveillance program. Clin Infect Dis 1996;23:779-84.

9. Biedenbach DJ, Moet GJ, Jones RN. Occurrence and antimicrobial resistance pattern comparisons among bloodstream infection isolates from the SENTRY Antimicrobial Surveillance Program (1997-2002). Diagn Microbiol Infect Dis 2004;50:59-69.

10. Chow JW, Fine MJ, Shlaes DM, et al. Enterobacter bacteremia: Clinical features and emergence of antibiotic resistance durring therapy. Ann Intern Med 1991;115:585-90.

11. Gales AC, Jones RN, Turnidge J, Rennie R, Ramphal R. Characterization of Pseudomonas aeruginosa isolates: Occurrence rates, antimicrobial susceptibility patterns, and molecular typing in the global SENTRY antimicrobial surveillance program, 1997-1999. Clin Infect Dis 2001;32(Suppl 2):S146-55.

12. Lautenbach E, Strom BL, Nachamkin I, et al. Longitudinal trends in fluoroquinolone resistance among Enterobacteriaceae isolate from inpatients and outpatients, 1989-2000: Differences in the emergence and epidemiology of resistance across organisms. Clin Infect Dis 2004;38:655-62.

13. Neuhauser MM, Weinstein RA, Rydman R, Danziger LH, Karam G, Quinn JP. Antibiotic resistance among gram-negative bacilli in US

\section{DO NOT COPY}

that adequately explains why Canada has been spared the rise in VRE that has been seen in the United States.

\section{SUMMARY}

The Canadian data available for surveillance of antimicrobial resistance within the hospital setting are limited. In the past 10 years, the Canadian Nosocomial Infection Surveillance Program has been addressing this issue, and with time, a more detailed analysis of prevalence rates and trends over time should become available. It is well recognized that several factors may be driving antimicrobial resistance, not the least of which are the overuse and misuse of antibiotics. It must be kept in mind, however, that because resistance genes may cluster together on the same plasmid or transposon, the use of one class of drugs may not only select for resistance to itself, but it may also select for resistance to totally unrelated agents (27). Time will tell whether we will be spared the alarming trends of increasing resistance seen elsewhere in the world. Continued surveillance, coupled with antibiotic stewardship, and infection prevention and control measures, remains key to our ability to understand and control resistance within our hospitals.

intensive care units: Implications for fluoroquinolone use. JAMA 2003;289:885-8.

14. Paladino JA, Sunderlin JL, Forrest A, Schentag JJ. Characterization of the onset and consequences of pneumonia due to fluoroquinolonesusceptible or -resistant Pseudomonas aeruginosa. J Antimicrob Chemother 2003;52:457-63.

15. Polk RE, Johnson CK, McClish D, Wenzel RP, Edmond MB. Predicting hospital rates of fluoroquinolone-resistant Pseudomonas aeruginosa from fluoroquinolone use in US hospitals and their surrounding communities. Clin Infect Dis 2004;39:497-503.

16. Low DE, Garcia M, Callery S. Methicillin-resistant Staphylococcus aureus - Ontario. Can Dis Wkly Rep 1981;7:249-50.

17. Simor AE, Ofner-Agostini M, Bryce E, et al; Canadian Nosocomial Infection Surveillance Program, Health Canada. The evolution of methicillin-resistant Staphylococcus aureus in Canadian hospitals: 5 years of national surveillance. CMAJ 2001;165:21-6.

18. Conly JM. Antimicrobial resistance in Canada. CMAJ 2002;167:885-91.

19. Conly JM, McEwen S, Hutchinson J, Boyd N, Callery S, Bryce E. Canadian Committee on Antibiotic Resistance report. Can J Infect Dis Med Microbiol 2004;15:257-60.

20. Canadian Committee on Antibiotic Resistance. Antimicrobial resistance: A deadly burden no country can afford to ignore. February 2002. <www.ccar-ccra.com/english/word/FinalReport2.doc> (Version current at March 3, 2006).

21. National Nosocomial Infections Surveillance (NNIS) System report, data summary from January 1990-May 1999, issued June 1999. Am J Infect Control 1999;27:520-32.

22. Gardam MA. Is methicillin-resistant Staphylococcus aureus an emerging community pathogen? A review of the literature. Can J Infect Dis 2000;11:202-11.

23. Martone WJ. Spread of vancomycin-resistant enterococci: Why did it happen in the United States? Infect Control Hosp Epidemiol 1998;19:539-45.

24. Lior L, Litt M, Hockin J, et al. Vancomycin-resistant enterococci on a renal ward in an Ontario hospital. Can Commun Dis Rep 1996;22:125-8.

25. Bradley SJ, Wilson AL, Allen MC, Sher HA, Goldstone AH, Scott GM. The control of hyperendemic glycopeptide-resistant Enterococcus spp. on a haematology unit by changing antibiotic usage. J Antimicrob Chemother 1999;43:261-6.

26. Fridkin SK, Edwards JR, Courval JM, et al. The effect of vancomycin and third-generation cephalosporins on prevalence of vancomycinresistant enterococci in 126 US adult intensive care units. Ann Intern Med 2001;135:175-83.

27. Levy SB, Marshall B. Antibacterial resistance worldwide: Causes, challenges and responses. Nat Med 2004;10(12 Suppl):S122-9. 


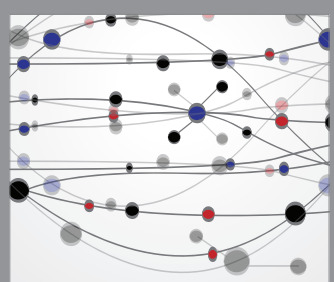

The Scientific World Journal
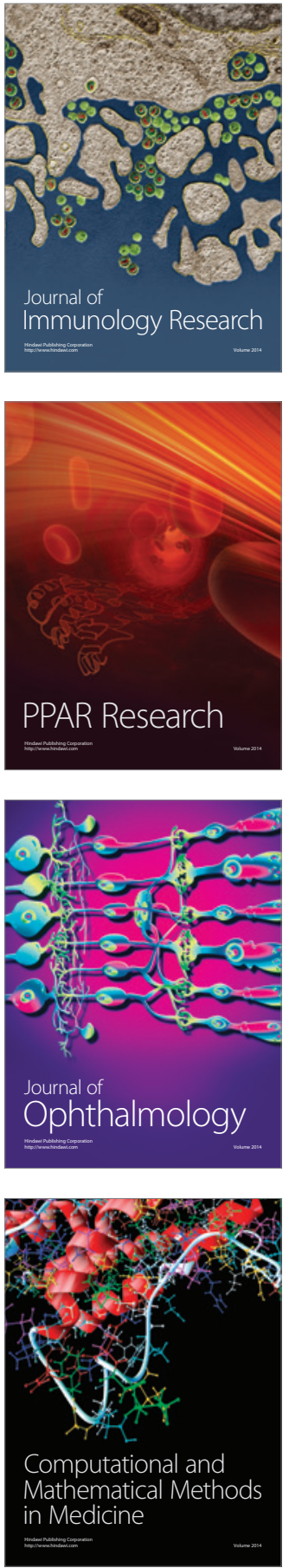

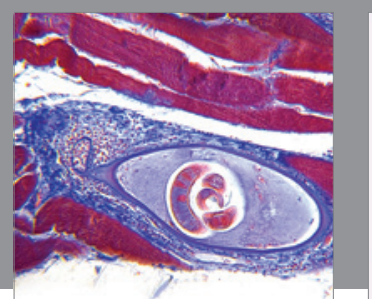

Gastroenterology Research and Practice

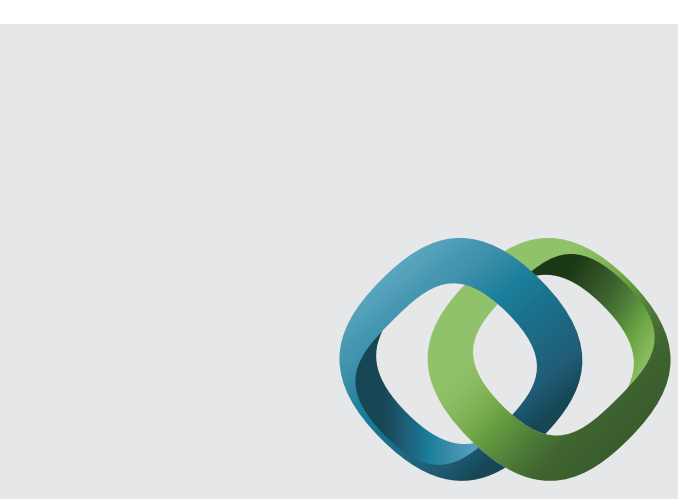

\section{Hindawi}

Submit your manuscripts at

http://www.hindawi.com
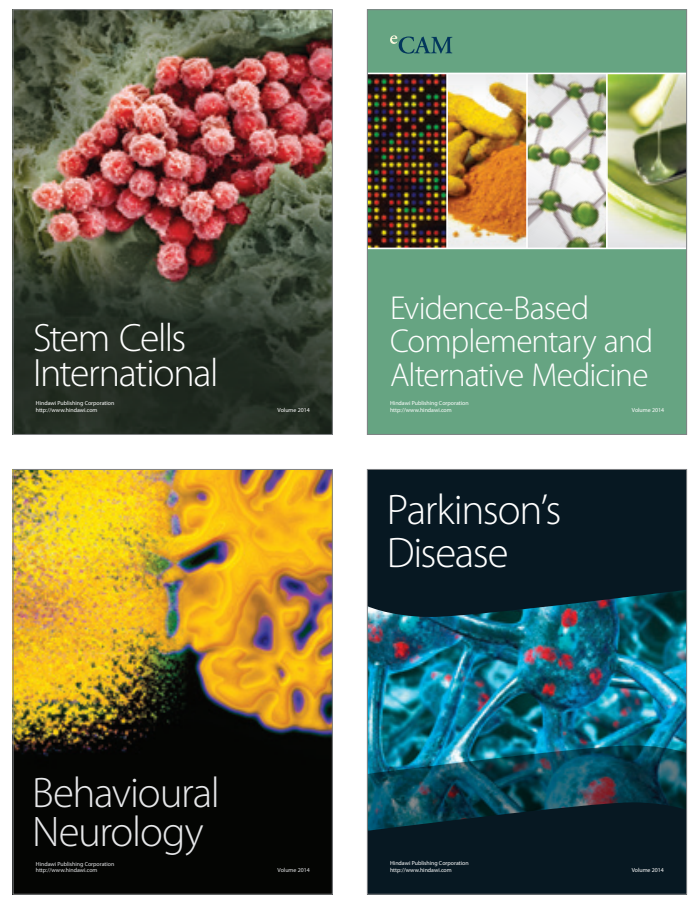
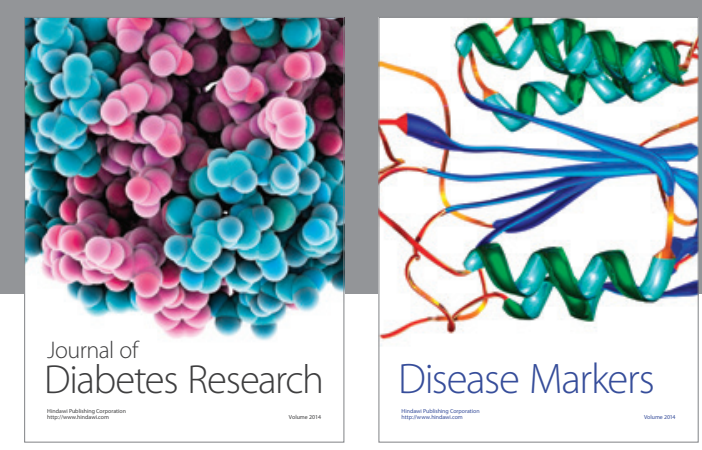

Disease Markers
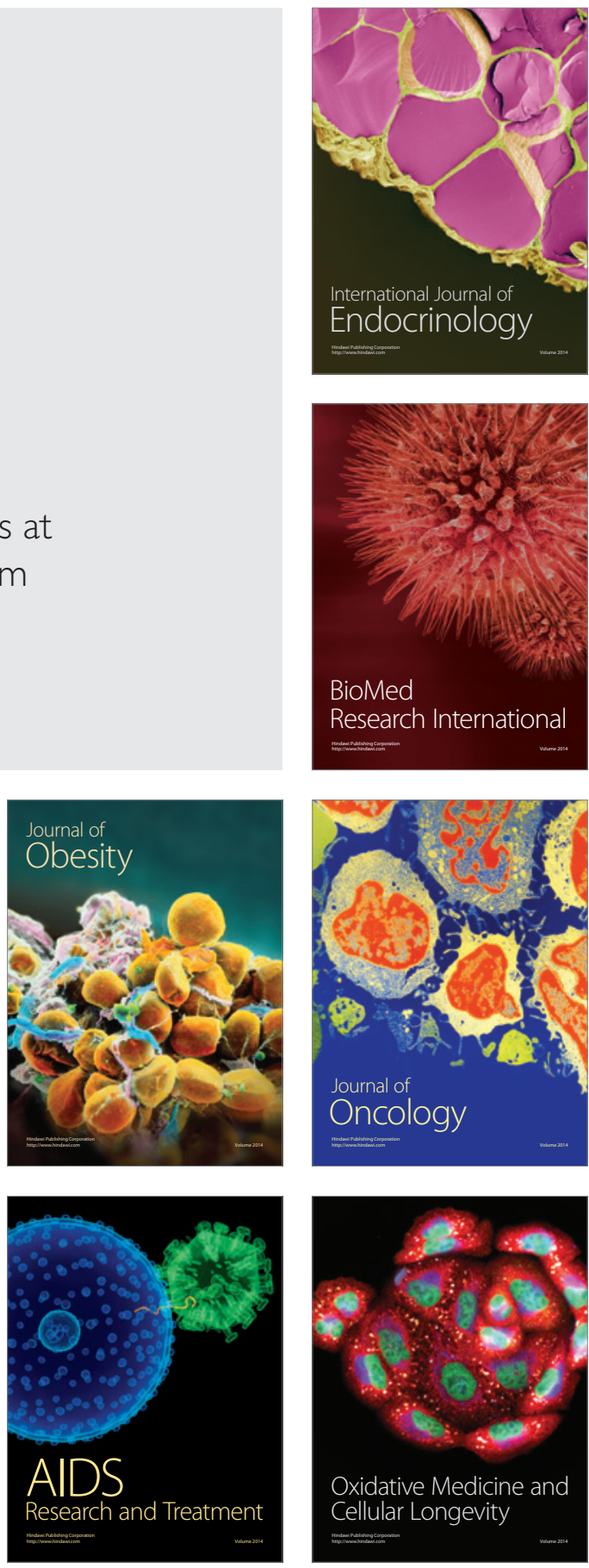